\title{
Long-awaited French anti-AIDS campaign is launched
}

Paris

THE French Minister of Health, Claude Evin, has finally disclosed government plans to step up national efforts to combat AIDS. The announcement follows a seven-month period without public health campaigns or response to complaints of financial asphyxiation from researchers and hospital staff. But the news is worth the wait: a tripling of government grants for AIDS research, quadrupling of funds for public health education, extra money for hospital care of AIDS sufferers, payment of damages to haemophiliacs infected by contaminated blood products and the creation of two non-governmental coordinating committees.

Reactions to the new AIDS programme have been favourable, with a general feeling that the government has finally appreciated the scale of the epidemic in mainland France. If the disease continues to spread at present rates (doubling every 11 months), there could be over 20,000 declared AIDS cases by the end of 1989 .

The budget for health education will be three times last year's, at FF100 million (\$16.13 million), of which FF50 million will be spent on national information campaigns in the media. A television campaign to promote use of condoms is scheduled for the end of November. The condom is still an unpopular and relatively expensive form of contraception in Catholic France and sales have been impeded by a jealously guarded pharmacy monopoly on sales of surgical and drug products. In addition to media campaigns, a further 4,000 health education specialists will be trained during 1989 to conduct campaigns centred on secondary school pupils.

With the priority of prevention in mind, Evin is aware that AIDS is spreading most rapidly among intravenous drug-users, particularly in the Paris area and in densely populated cities in the south of France. Evin will extend the decision taken by the last Minister of Health, Michèle Barzach, to make disposable syringes available over the counter in pharmacies. Systematic national screening for human immunodeficiency virus (HIV) is still being ruled out. But Evin wants blood tests to be routinely proposed to pregnant women believed to be at risk and to all new prison detainees. Condoms will be available in prisons, on request, from the prison doctor.

The cost to the health service of treating AIDS sufferers could cripple state health care, if the projected figure of one state hospital bed in six occupied by an AIDS patient within five years is realized. Evin has released an extra FF430 million for hospital care and has created an extra 200 new jobs, 30 of which will be reserved for medical practitioners. This is unlikely to be adequate, so Evin has set up a special working group to study the future impact of the epidemic on the health service.

The AIDS research budget will rise to FF150 million from FF50 milion. But the figures are misleading. In May, Luc Montagnier of the Pasteur Institute complained that government grants for AIDS research had dropped from FF150 million to FF20 million. Although this sum was later apparently boosted to FF70 million, both the health and research ministers said that it was pointless to give more money because it was not being spent. About FF50 million of the 1987 AIDS research budget was, indeed, left in the bank at the end of the year and was carried over to 1988 . But one leading researcher says that this was because the research ministry took a year to pay its bills, not because the money had not been spent.

Evin is proving a believer in working groups and committees. To oversee AIDS research spending, he will set up a nongovernmental science committee "to stimulate, coordinate and evaluate" research in all sectors. He hopes its membership and scope will be Europewide, if other countries agree. A national AIDS committee will also be established, comprising 15 as-yet unnamed specialists, to "discuss, to propose and to recommend". The ministry of health will also have a special agency to oversee public health campaigns.

Peter Coles

\section{ESA science projects due to be chosen}

Paris

FIVE projects competing for a place in the European Space Agency's (ESA) Horizon 2000 long-term space science plan were presented in Bruges, Belgium last week. A final choice of one project will be made at ESA's Science Programme Committee meeting on 24 and 25 November. The five projects are:

CASSINI - a Saturn orbiter and Titan probe;

GRASP — gamma-ray astronomy with spectroscopy and positioning;

LYMAN - High resolution spectroscopy in the 900-1,200 $\AA$ band;

QUASAT - a space VLBI satellite;

VESTA - missions to asteroids and comets in the solar system.

Following design and development starting next year, the selected project should be ready for launch in 1996.

\section{US-Soviet talks on psychiatry}

\section{Washington}

THE latest step in a complex dance between the United States and the Soviet Union over alleged abuses in Soviet psychiatry is scheduled to take place this week; a small but official delegation from the United States is visiting the Soviet Union to work out logistics for a visit by a formal investigating team early next year. Although the visit makes US officials optimistic that the debate over abuses can be resolved, they say there is still a long way to go before psychiatry can be added to the disciplines in which the two countries can collaborate.

IIl feeling between the two countries reached a peak in 1983 when the All Union Society of Psychiatrists and Neuropathologists of the Soviet Union resigned from the World Psychiatric Association (WPA) because of efforts by the Ameri-

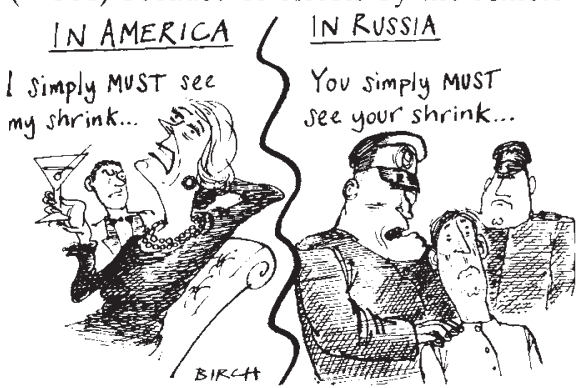

can Psychiatric Association (APA) to have the society expelled for psychiatric abuses. In the past few years, Soviet health officials have sought to remove US objections to Soviet psychiatric practices, and have tried to invite US health officials to inspect Soviet facilities. But the United States has asked that an APA representative be included in any delegation.

There appears to be a shift in Soviet attitudes. The Soviet Union has reapplied for admission to the WPA, and has accepted an APA representative as a member of the visiting team now being assembled. The visit will be held under the auspices of the US State Department, with representation from the National Institute of Mental Health. The State Department believes that the flexibility the Soviet Union is now showing is intended to create a good impression with WPA. Loren Roth, a forensic psychiatrist from the University of Pittsburgh, will lead the delegation.

By a coincidence of timing, at the same time as the logistical team for the psychiatric visit is in the Soviet Union, a delegation from the US Department of Health and Human Services is in Moscow to review progress and plan new activities under their joint health agreement, but US officials stress that psychiatry will not be discussed. Joseph Palca 